\title{
ETHNOECOLOGY AND CONSERVATION IN PROTECTED NATURAL AREAS: INCORPORATING LOCAL KNOWLEDGE IN SUPERAGUI NATIONAL PARK MANAGEMENT
}

\author{
PEDROSO-JÚNIOR, N. N. and SATO, M. \\ Programa de Pós-graduação em Ecologia e Recursos Naturais, Universidade Federal de São Carlos \\ (PPGERN/UFSCar), Via Washington Luís, km 235, C.P. 676, CEP 13565-905, São Carlos, SP, Brazil \\ Correspondence to: Nelson N. Pedroso-Júnior, Programa de Pós-graduação em Ecologia e Recursos Naturais, \\ Universidade Federal de São Carlos (PPGERN/UFSCar), Via Washington Luís, km 235, C.P. 676, CEP 13565-905, \\ São Carlos, SP, Brazil, e-mail: nelsonnovaes@uol.com.br
}

Received October 17, 2002 - Accepted November 19, 2003 - Distributed February 28, 2005

(With 1 figure)

\begin{abstract}
The majority of protected natural areas in Brazil were created in coastal areas inhabited by humans for centuries. However, legal protection has triggered a series of conflicts involving human settlements in these areas. To overcome part of these problems, ethnoecological studies have been conducted in order to discover what is known by local indigenous communities with respect to the land, its natural cycles, occurrence and abundance of animal species, and their use. This knowledge, coupled with that acquired in dealing with current situations that negatively affect the quality of life, is useful in protected natural-area planning and management. To that end, the present study proposes environmental education based on ethnoscientific methods, designed to facilitate the maintenance of sociodiversity in the Superagui National Park.
\end{abstract}

Key words: ethnoecology, terrestrial fauna, protected natural areas, caiçaras, environmental education.

\section{RESUMO}

\section{Etnoecologia e conservação em unidades de proteção: incorporando o saber local à manutenção do Parque Nacional do Superagui}

Grande parte das unidades de conservação no Brasil foi criada nos espaços litorâneos, habitados secularmente por populações humanas, por isso surgiu uma série de conflitos envolvendo a permanência dessas populações nessas áreas protegidas. Buscando solucionar parte desses problemas, estudos etnoecológicos vêm sendo desenvolvidos visando a resgatar o conhecimento que as comunidades humanas locais têm sobre o ambiente terrestre, os ciclos naturais, a ocorrência e a abundância de espécies animais, bem como os usos e valores a eles atribuídos. O resgate e a valorização desse conhecimento aliados ao levantamento das problemáticas que estão interferindo negativamente na qualidade de vida, como também de meios e alternativas para solucioná-las, são instrumentos úteis no planejamento e no manejo de uma unidade de conservação. Assim, este estudo propõe uma educação ambiental baseada em métodos etnocientíficos como mediadora de um diálogo que vise à manutenção da sociodiversidade da região abrangida pelo Parque Nacional do Superagui.

Palavras-chave: etnoecologia, fauna terrestre, unidades de conservação, caiçaras, educação ambiental. 


\section{INTRODUCTION}

The content of a given society's imagination has been an important factor in the process of anthropic modification of the environment, a dialectical relationship in which nature itself is involved. Stories, myths, and customs in different historical phases have characterized regional human settlements and their relationship with nature. Western society, for instance, was established and developed based on its primary economic conviction: the necessity of economic supremacy, entailing predatory methods of land appropriation and occupation, which has introduced throughout the world growing uncertainty as to this model's sustainability. As a result of the rapid growth of urban-industrial societies, some concern gradually began to emerge regarding natural ecosystems and their increasing destruction in the wake of industrialization, among other causes.

In order to minimally guarantee the preservation of vulnerable ecosystems in the face of anthropic threats, the concept of protected natural areas arose. Such areas are known in Brazil as Conservation Units (Adams, 2000). They were created at a time during which a bio-centric conception of the relationship between humans and nature was current, which resulted in a neo-myth exalting untouched nature (Diegues, 1994) and exemplified in the creation of national parks in the United States. In the middle of the nineteenth century, territories considered untouchable were legally designated protected natural areas, which automatically precluded human occupation. The implantation of this policy, however, was not feasible in tropical countries like Brazil, whose forests have been inhabited by humans who for centuries had lived in direct contact with nature, evolved specific lifestyles, and whose continuation depended on renewable natural resources. But that difference was overlooked when Brazilian conservation units were established without regard for the needs of local communities, which in large part were removed from the areas that had been the site of their ancestral homes (Diegues \& Nogara, 1994; Maldonado, 1997; Da Silva, 2000).

A large part of the Brazilian conservation units were established primarily in coastal territories covered by tropical forests and inhabited by impoverished and illiterate populations with very little political power. These people were also relatively isolated, living in areas without potential for economic development (mangroves, marshes, tropical forests), and lacking legal rights to their land (Diegues, 1994).

Inhabitants located on the Brazilian coast, the first region occupied, are in some cases direct descendents of the original white settlers of the coastal states of Rio de Janeiro, São Paulo, and Paraná and, not surprisingly, present common cultural and social characteristics. They were those not participating in the gradual resettlement further inland, primarily on southern plains and plateaus more and more distant from the coast (Mussolini, 1980). These people, the caiçaras, are an ethnic-cultural mixture descended from indigenous stock, Portuguese settlers, and African slaves (Mussolini, 1980; Viana, 1996; Adams, 2000; Diegues \& Arruda, 2001), continue to live in the same coastal regions where a considerable number of conservation units are concentrated, and which during recent decades have been the scene of successive conflicts involving land rights.

If global bio-diversity protection and management have been prioritized in current sustainable development discussions (e.g., UICN, 1984; UICN/ PNUMA/WWF, 1991; WRI, 1992), it was only after the 80s that international interest began to focus on the value of accepting the presence of already existing human communities in protected natural areas. Much attention has been given to the cultural aspects of this change in approach. For example, popular knowledge and the local people who are its repository, which before had been considered irrelevant, came to be regarded as essential to management planning (Hanbury-Tenison, 1991). The obvious proof is that within the past few years ethnobiological information obtained in collaboration with local communities has become an important tool for environmental research, useful in accumulating knowledge of plants and wildlife, and also for pinpointing elements potentially valuable in regional development (NAS, 1992).

As an example, the Guaraqueçaba Environmental Protection Area (EPA), on the northern coast of Paraná State and in which Superagui National Park is located, shows a remarkable level of conservation due to its relative politico-geographic isolation, difficult access and low demographic density, and currently represents the largest remains of the Atlantic Rain Forest (Mata Atlântica) in Brazil (SPVS, 1999). This biome has been reduced to less than $8 \%$ of its original covering and is considered one of the hotspot areas for global bio-diversity preservation (Myers et al., 2000). 
The region also counts more than 50 communities that survive basically from small-scale agriculture and fishing. However, within the last 3 decades this region has undergone an intensive process of economic, social, and cultural transformation, attributable mainly to limited access to natural resources resulting from the creation conservation units, but also to tourism, growing real estate speculation, substantial decrease in agricultural, and fishery specialization and intensification. These changes can be linked to the present state of impoverished knowledge regarding local environments and wildlife, a loss which triggers subsequent losses in local cultural variability, possibly rendering communities less able to cope with changes, and thus affecting the resilience of local structures (Begossi, 2000). The kind of knowledge lost is based on experience, transmitted by oral tradition, and represents an important resource in regional management and conservation. Based on ethnoscientific methods, the present study analyzed the empiric knowledge of two communities, the villages of Tibicanga and Peças, on the island of Peças, with respect to the terrestrial environment, especially wildlife, at the same time in which new and exogenous knowledge is being incorporated. From this analysis, we expect to identify element useful in future environmental education (EE) projects based on ethnoecological research carried out in this region. This contribution aims at strengthening the link between cultural and social diversity, by examining the degree of community awareness of the aspects of nature that influence their history and social characteristics, in accordance with the recommendations of Agenda 21, the Carta da Terra, and the EE treaties. This study aims to unify academic and popular knowledge to formulate a methodology that values the local community, its needs and hopes.

\section{MATERIAL AND METHODS}

\section{Study area: Superagui National Park}

Superagui National Park includes a total area of 33,988,00 ha and is located on the northern coast of the State of Paraná, in the city of Guaraqueçaba, between coordinates: North $-25^{\circ} 12^{\prime} 21,79^{\prime \prime} \mathrm{S}$ and $48^{\circ} 10^{\prime} 39,33^{\prime \prime} \mathrm{W}$; South $-25^{\circ} 29^{\prime} 18,50^{\prime \prime}$ 'S and 48 $177^{\circ} 28,43^{\prime}$ 'W; East - $25^{\circ} 13^{\prime} 49,60^{\prime \prime} \mathrm{S}$ and $48^{\circ} 01$ ' $31,38^{\prime \prime}$; and West $25^{\circ} 24^{\prime} 48,32^{\prime \prime} \mathrm{S}$ and $48^{\circ} 20^{\prime} 35,12^{\prime \prime} \mathrm{W}$ (Fig. 1). It is a part of the Lagune-Estuarine Complex of IguapeCananéia and Paranaguá, having approximately 5,800 $\mathrm{km}^{2}$ and extending $200 \mathrm{~km}$ on the coast from the north of Juréia Ecological Station, in São Paulo, to the city of Pontal do Sul, in Paraná (Vivekananda, 2001). The park includes the islands of Peças and Superagui, besides the Rio dos Patos plain (on the continent), which presently counts 15 small communities. The three most populated ones are Barra do Superagui, on the island of Superagui, and Tibicanga and Peças villages on the island of Peças. Both communities of Peças Island have been studied, with the largest (Peças village) having about 196 households with approximately 278 permanent inhabitants, while Tibicanga village, with no more than 200 inhabitants, numbers about 55 households (SPVS, 1995).

The main ecosystems in the region are rain forests, mangroves, restingas (coastal pioneer forest on sandy soil), dunes, and beaches. Regarding wildlife, examples of endangered species likely to be found are: the black-faced lion tamarin (Leontopithecus caissara), the blue-cheeked parrot or chauá (Amazona brasiliensis), the puma (Felis concolor), and the howler monkey (Alouatta fusca) (SPVS, 1999). However, limited research has been done on animal population biology and ecology, except for two endangered species near extinction: the blue-cheeked parrot and the black-faced lion tamarin, the latter of which was discovered and described by researchers only in 1990, when some individuals were recorded in the Park one year after its creation.

The park is situated in the EPA of Guaraqueçaba, which includes estuary areas, islands, mangroves, sand ridges, Serra do Mar mountains, elevated plains, and several conservation units. Outside the Park, is Guaraqueçaba Ecological Station, with 14,000 ha, which was created to protect the mangroves and restinga areas. Since 1991 this region has also been included in the Biosphere Reserve Program (MAB/UNESCO) (IPARDES, 1997). In conclusion, the EPA serves as a barrier zone for protected natural areas, while at the same time the Superagui National Park is not completely isolated.

\section{METHODOLOGY}

The bibliographic survey and field research were primarily done on human settlement in the region of Guaraqueçaba, specifically on Peças island, the Superagui National Park, and relevant socio-economic and cultural aspects of its inhabitants. It concentrated on environmental education and conservation biology as applied to local wildlife, in addition to those EE projects already being carried out in this region. 


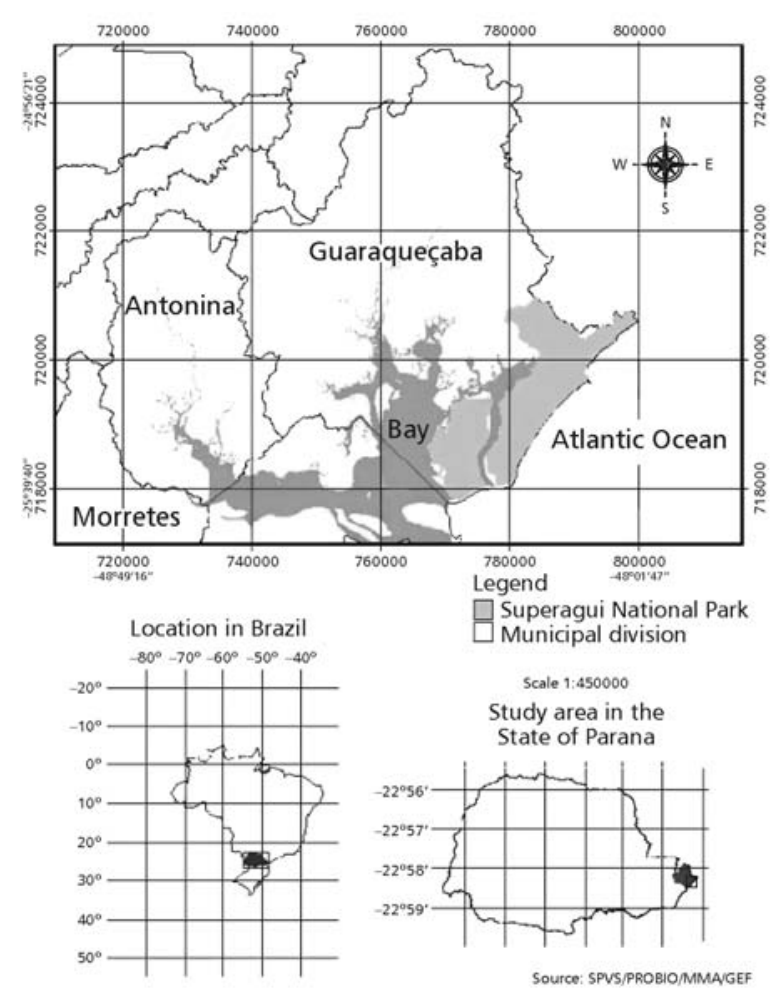

Fig. 1 - Localization of Superagui National Park.

During the next phase, four visits to Tibicanga and Peças villages were made, lasting three days each, in the months of February, May, August, and November of 2001. Within this period, non-directive interviews (Chizzotti, 1995) were applied to different interacting groups (children, their teachers, and eldest residents). These were designed to reveal changes in the past and current use of the terrestrial environment and, more specifically, in feelings, behavior, beliefs, knowledge, and perceptions regarding terrestrial fauna. Current community problems were also discussed, as well as the possible alternatives for their solution that can be arrived at with suitable education.

In Tibicanga, interviews were conducted with two teachers, five elderly residents, and three children. In Peças four teachers, seven elderly residents, and four children were interviewed. All interviews made use of a mini-recorder and were subsequently transcribed onto a computer. For the children, this method proved unsatisfactory owing to their general and eager responsiveness, which precluded orderly interviewing. All of them obviously preferred to play with the recorder rather than to answer the interviewer's questions. Therefore, it was decided that the researcher would dispense with the recorder in addressing the main issues involved in the research, which was also the case with informal conversation with the elders.

Finally, for purposes of analysis and discussion, the data obtained from the bibliography, in publications, and by examining environmental education activities, were considered in the light of the interview results (perception of elders, community children, and teachers).

The qualitative analysis, which takes into consideration the phenomenological character of the data, was based on ethnoscientific methods. Marques (1995) defined ethnoecology as a product of the combination of interdisciplinary fields, which studies how populations are culturally inserted in ecosystems through cognitive processes, like emotional and behavioral responses, from which connections emerge. These connections reveal an interpenetration between society and nature in which these two components complement, and even contradict, each other. Elements, such as human emotions, are examples that demand (if not exclusively), a qualitative complementary approach. The importance of such an approach is not that, as described by Bogdan \& Bikien (1994), it answers questions or tests hypotheses. Rather, it provides a way of understanding behavior and emotion 
through the perspectives of the people interviewed, by data accumulated by extensive contact with them in their ecological context.

Since ethnoecology is defined as an essentially interdisciplinary research field, several qualitative research methods and techniques can be used, like the phenomenological. This type of approach seeks to penetrate the conceptual world of its subjects (Geertz, 1973), the objective being to understand the content upon which the significance of the lives of a given people is constructed. This study used a phenomenologically oriented approach, in retrieving a given community's history, and through local myths and legends, attempting to learn about the population through uncovered symbolic interaction with the natural environment. Although seeking to identify subjective individual (cognitive) categories, the final result allows insight into the fundamental system as well as into stable components of cultural significance. This study is an example of an approach using ethnoscientific methods and based on the Posey (1987) doctrine.

As for the non-directive interviews, in general the more open, less restrictive, and fewer the questions asked, the greater the freedom of the respondent to answer using his own logic and concepts. In this case, dialogues originated in an interview conducive to informal conversation, where the stories told and the symbologies that run through them allow the emergence of useful data in analysis. Although nondirective, the interviews are partially structured (Gil, 1999) in order to lead the dialogue when the questions of interest are strayed from.

In relation to the subject of animals, the different uses of, and values attributed to, each species (e.g., dietary, medicinal, and recreational) were analyzed using the ethnozoological categories proposed by Marques (1995).

\section{RESULTS AND DISCUSSION}

\section{Present and past use of the terrestrial environment}

The analyses of information obtained through interviews and conversations with the eldest residents of Peças and Tibicanga, in addition to related bibliography data, clearly show a succession of structural changes in the local population's perception and use of the terrestrial environment on Peças island. Subsistence fishing had always been the main activity of men from both villages, even though other pursuits linked to the forest have played more a important role in maintaining the communities. Near-beach areas in the vicinity of the villages were utilized to build houses and shelters for boats and canoes. Right beyond the beach, clearings were made for agriculture, the products of which were destined for family subsistence while the surplus was sold in larger centers, like the cities of Guaraqueçaba and Paranaguá.

The main crops were manioc, coffee, oranges, rice, beans, watermelon, pumpkin, corn, and some vegetables, supplementing a fish-based diet. The forest provided firewood, in addition to the raw material for the building and repairing houses, fishing huts, fences, canoes, boats, and fishing supplies. The palmetto (Euterpe edulis) was harvested for marketing; the caixeta (Tabebuia cassinoides), for manual craftwork and construction; and the tucum palm (Bactris setosa), to make fishing nets and string. Hunting provided food for local consumption, with the surplus being commercialized.

However, in recent decades these communities have undergone several changes. With the advent of the motorboat, beginning mainly in the $50 \mathrm{~s}$, communication between villages and major population centers became easier. Consumer goods were arriving in larger quantities. Motor-powered vessels led to specialization and intensification of fishing, guaranteeing discretionary income allowing the purchase of food products until then produced by the communities themselves, in addition to other goods. A direct consequence was a reduction in agriculture, which was accentuated with the creation of the National Park in the 80s that limited the area available for cultivation. Environmental laws and their enforcement, the responsibility of the Environmental Institution of Paraná/IAP, the Brazilian Institute for the Environment, and Renewable Natural Resources/IBAMA, and the forest rangers, have been the major agents for structural changes in forest resource use by local inhabitants. Palmetto extraction, and on a smaller scale that of caixeta, formerly important sources of many family incomes, mainly in the winter months when fish are scarce. This now prohibited activity is presently engaged in by very few. Tree cutting for firewood has decreased significantly, due to the gas stoves and electricity now common in Peças, while in Tibicanga, unserved as yet by electricity, firewood is still used. Animals are still a food source, but less intensively than in the past. 


\section{Terrestrial fauna perception}

Of the four terrestrial vertebrate classes, not one amphibian had been found when the data gathering was concluded, although some species of toads, frogs, and tree-frogs are common in the region, and present in the inhabited areas. The Reptile class was mentioned as having nine ethnospecies by adult narrators, who exhibited special regard for a lizard, Tupinambis teguixim, considered the most useful animal because of its fat which is extracted and employed in traditional medicine, and the meat of which serves as food. Another generally cited reptile was the alligator, Cayman latirostris, whose meat and fat are used in the same way as the lizard's. The snake species mentioned were the jararaca (Bothrops jararaca); jaracuçu (Bothrops jararacussu) and coral, both considered dangerous; and the caninana (Spilotes pulatus), also called the "meek snake". The children only mentioned three ethnospecies of reptiles: the lizard, alligator, and snake, not identifying them at the species level and viewing them as dangerous. But, following the adults, the children also identified the lizard as a fat supplier, and important to the multipurpose medicine used in the studied communities.

The other two vertebrate classes, Birds and Mammals, are commonly known and cited. These animals were generally divided in two larger categories: quarry and small birds. For quarry, the mammals are not distinguished by whether or not they are used as food. [Some birds, i.e., the brown tinamou (Crypturellus obsoletus), guan (Cracidae), and pigeon (Columbidae), as well as mammals (members of the felidae and canidae families) are not so used.] Compared to the adults, the children mentioned fewer species hunted, not even mentioning the brocket (Mazama sp.), which was one of the most spoken of by their elders. The armadillo (Dasypus sp.), paca (Agouti paca), aguti (Dasyprocta azarae), capybara (Hydrochaeris hydrochaeris), crab-eating fox (Cerdocyon thous), the jaguar (Panthera onca), the puma (Puma concolor), and the small cats (Leopardus sp.) were the most recalled animals by both age classes.

The remaining birds were referred to as small birds, among them including a range of Passeriformes species unidentified at the species level. The most known birds are those that also exist in the surroundings and in inhabited areas and which, due to their typical behavior, song, and/or plumage, are more noticed. These include species such as the saffron finch (Sicalis flaveola), collared seedeater (Sporophila caerulescens), Brazilian tanager (Ramphocelus bresilius), blue jay (Cyanocorax caeruleus), thrushes (Turdus sp.), quits (Coereba flaveola), and hummingbirds (Trochilidae), some of which are prized as pets. The children mentioned no species typical of forested areas, unlike the adults, who mentioned some of the most notable ones, like the purple-throated fruit-crow (Pyroderus scutatus), the tayra (Eira barbara), and also the porcupine (Coendou villosus), besides the seed finch (Oryzoborus angolensis), seemingly extinct in the area and only remembered by the eldest narrators. From non-Passeriformes, the one that most stood out most prominently was the blue-cheeked parrot (Amazona brasiliensis), common in the area and an object of attention in conservation campaigns in the region. Other quite remarked on species were those found along the beaches, rivers, and mangroves of the area, e.g. egrets (Egretta sp.), herons (Ciconiidae), woodrail (Aramides cajanea), and the frigatebird (Fregatta magnificens).

\section{Human/animal connections}

Several forms of human/animal connections were observed, although most of the species involved had only been mentioned, without attributing specific values or citing characteristics. Among the connections noted, however, the most frequent were utilitarian, and use for food the most common. Most of the mammal species were so used, most notably the armadillo, paca, aguti, brocket, anteater (Myrmecophaga tridactyla), and porcupine. Birds are less hunted and consumed. With the exception of the brown tinamou, which is relatively abundant in the area, game species such as woodquails (Odontophorus sp.), guans, and the solitary tinamou (Tinamus solitarius) do not exist on the island.

Another quite frequent use is for medicinal purposes, the most mentioned being the fat of certain animal species. Among them, lizard fat is the most widely used for medicinal purposes, as testified to by the fact that all adult interviewees made mention of several species and their respective uses. In addition to the lizard, the fat of other species (the capybara, opossum (Didelphis sp.), alligator, anteater, and porcupine) as well as the brocket deer hoof, paca bile, and feathers of the brown tinamou were also cited as medicinally useful. Other utilitarian uses of wildlife, e.g., as pets, barter items, or breeding are very rare. During this study, only two caged animals were observed, both of the same species: the double-collared seed eater, Sporophila 
caerulescens. But other species were also mentioned for their former use as pets, in addition to being used for trade, a practice attributed to the Guarani indians that inhabited the island until the middle of the last decade.

Some people demonstrated an ambivalent connection with some animals such as the otter (Lutra longicaudis) and the alligator, which damage fishing nets or abscond with already caught fish. The crabeating fox, small cats, lizards, and opossums were also described by a few interviewees as harmful since they attack domesticated animals even though two of them also provide meat for consumption and fat for medicine. Another ambivalent category includes animals considered dangerous, like snakes (mainly the jararaca and jararacuçu). The puma and jaguar, although considered dangerous by the minority, provoke great admiration and speculation as to their whereabouts once their presence is confirmed by abundant footprints or other evidence.

Some animals are cited by reason of their aesthetic-recreational values. These include many birds, admired by the adult population mainly for their behavior, song, and/or plumage. The children still play with slingshots, and they mention certain species of birds as their favorite targets.

The blue-cheeked parrot was the most mentioned species of all for its ecological value, mainly among the children. Among the adults, no particular species was remembered solely for its ecological value.

Finally, one species was revealed to be part of a mythical connection: the saci (Tapera naevia), which is still associated with a young one-legged black man who whistles from within the brush to confuse to the point of getting lost folk who have wandered far from the village. Some children even credit the saci with having a whip to punish anyone straying beyond cultivated vegetation. The elders say that nowadays their legends and myths, while no longer influencing the majority, continue to be narrated by some. One of the challenges of EE, therefore, is to resurrect these myths, as well as values and symbols gleaned from accumulated popular wisdom, which the globalization phenomenon in effect buries under the weight of values typically induced by marketing and science.

\section{Ethnoecological knowledge}

Of the interviewed inhabitants of Peças island, all said that the species living on the island are few relative to those in the mountainous area adjacent to the park. The reason cited for the great diversity of animal species in the sierra is its greater arboreal species richness, larger biomass, and fruit quantity and variety. Regarding animal-species abundance, while all the adult interviewees affirmed that the animal population has decreased and some species have even become extinct, their explanations for this impoverishment vary. Some stated that the animals still live on the island, but they are not as easily seen due to population growth in the villages, where nocturnal illumination and noise, particularly that of motorboats, drive away the wildlife to the center of the island. Others attribute the decline in wildlife to past overhunting; yet others cite religious beliefs in their explanations.

Animals such as the brocket deer were recalled by all adult interviewees as being one of the most important game species, in addition to being constant visitors of their manioc plantations, which are rarely found nowadays. The children did not even mention brocket deer, although other interviewees said that members of this species are quite rare now, as are capybaras, by some even considered extinct in the region. The seed-finch (Oryzoborus angolensis) was recalled only by the eldest inhabitants who affirmed that the species is extinct in the area due to past years of overhunting.

In the winter months an increase in richness and abundance of passeriformes that visit the inhabited areas and surroundings has been noticed, mainly on the aroeira and guapê trees that are common throughout the villages. During this time the children shoot birds with their slingshots, a practice condemned by their teachers, who guaranteed us that the number of children still using slingshots to kill birds has decreased significantly.

A term widespread among the people interviewed is that each animal has its own "time", an allusion to the reproductive period of the species. That of most birds is evidenced by their vocalization: some species, like the bellbird Procnias nudicollis, only sing/chirp during this time; others, such as thrushes, vocalize all year long, but with increased intensity during its procreation time.

\section{Environmental fiscalization and prohibitions versus alternatives}

Although the major complaint of everybody questioned was related to environmental legislation and enforcement regarding fishing, by which they had previously been sustained, most agreed with the 
prohibition of hunting, which if it had continued at the same rate as in the past would by now have decimated all wildlife on the island. However, hunting for food is still tolerated and practiced, though less intensively than before. But environmental legislation and fishing restrictions, added to the National Park creation, have limited the sources of income for the population which, in the absence of other means of survival, can ultimately present an even greater threat to the forest resources and, consequently, wildlife.

The only source of income is fishing, since marketing the products of local vegetation and hunting are prohibited. One of the few possibilities may be tourism, which while only beginning is already highly regulated. Currently, although during the periods when fishing is prohibited the fishermen are entitled to receive a subsistence-level income, payment is not always prompt. Added to that, there are the winter months, known as the "hard" months, when fish become even scarcer.

The old-style fishermen are hard workers going daily out to sea to catch the family food supply. Lacking the means to accumulate capital, fishing is still their only means of subsistence. But whereas in former times, when fishing failed, they naturally turned to the forest to extract palmetto and caixeta, for hunting, and to plant for family needs, this alternative no longer exists. Thus, the inhabitants are forced to violate the law, some by seeking their luck in the forest, and most by going to sea in search of fish and shrimp. Frequently, these men come back empty handedly, their fishing equipment sometimes having been confiscated by law enforcers (not always sufficiently trained) who, besides fining them, often treat these fishermen with physical violence. This situation makes it more difficult for local people to feel identified with the conservation and maintenance objectives of the National Park, an attitude which is a crucial factor in the success of conservation unit management. The local population perceives itself as more and more restricted in what it can do and where it can go. These people are not offered alternatives, and have no voice in decision making. Many end up in nearby urban centers, forced to look for better living conditions for their families, adding to the slum population, and almost always becoming frustrated by lack of work. Those that persist in the villages are encouraged by what they consider viable alternatives, e.g. tourism development or oysters, shellfish, and shrimp farming, but without adequate cooperation, planning, and incentives from both the government and nongovernmental organizations, success is unlikely.

\section{Cultural and environmental preservation}

It has already been stated that these village populations have always maintained strong ties with the environment and have subsisted by using natural resources, and in doing so have established an intricate web of relationships that characterizes them as a component of a dynamic and complex socio-cultural and environmental system. However, in the last decades several elements have destroyed some of these links, causing structural changes in the population's lifestyles. Concepts, such as preservation, ecology, and environment, introduced and spread by the larger, technocratic society are gradually assimilated, becoming a part of a community's daily life. This can be observed in local speech as, for example, when community members say that nature should be preserved for their children and grandchildren, or that the parrot is an important animal species as it is now threatened with extinction. At the same time, these people feel neglected in comparison to the animals and plants of the region. They also interpret environmental law as casting they themselves in the role of environmental enemies while overlooking their part in helping to maintain the current conservational status of the region.

The need of these populations to actively participate in the Park management is evident. Their job as allies and agents of the conservation process must be recognized. It is the responsibility of EE to stress the importance and value of this culture, which has an intrinsic alliance with nature. One of the great challenges of EE is to make clear the importance of preserving biodiversity, while simultaneously inculcating the importance of, and respect for, local communities.

The Society for Wildlife Research and Environmental Education (SPVS), a NGO headquartered in Curitiba, Paraná, is intensely active in the Guaraqueçaba region. It has been developing a series of EE activities in collaboration with various communities, mainly focusing on blue-cheeked parrot conservation. In Tibicanga, only one lecture occurred at the end of the 90s, while in Peças, parallel with the study and monitoring nesting and breeding aspects of the species, a succession of EE activities is being carried out, including lectures, poster exhibitions, use of puppets and theater, addressing questions mainly regarding the smuggling and the conservation 
of the parrot (SPVS, 1998). However, these communities are resistant to these programs because, once more, they feel neglected in relation to animal species, and undervalued since they no longer hunt or sell the parrots as in former times. Because of this perception, ethnoscientific studies are extremely useful because they support proposals aimed at rectifying this situation. The results can be deduced from the children's almost unanimous comment on the parrot: "...it is important for nature". However, their slingshots still widely used, not to kill parrots but thrushes, doublecollared seed eaters, and tanagers, perhaps regarded as "less important" species than the famous bluecheeked parrot. Thus, formal education continues being the major factor in these children's outlook, and teachers are currently striving to see that the students in their care become conscious of their role not only as products of nature, but also as agents directly responsible for its conservation. However, this process sometimes has produced conflicting emotions in children aware of family difficulties created by the change. In relation to use of their slingshot, they question how that can be objectionable since these were give to them by their own fathers. Or when teachers claim that preservation is important for subsistence and improvement in their quality of life, they reply that their grandfathers are outraged by environmental prohibitions and abusive control measure. In addition, they refer to their elder's belief that ecology and progress bear no relation to one another.

It would be well to realize that many EE propositions limit their strategies to distributing information through lectures, courses, or educational/ recreational activities. A different line of EE research would try to integrate the two terms of this equation: the autonomy of the local populations as well as awareness of responsibilities in conserving the ecology in which they are embedded. Environmental education proposals must invite them to see themselves as agents in the construction of their own history, by acting to the benefit of nature, with minimum detriment to their own cultural values. Mankind is part of the web of life and the manner in which its insertion is presented can either benefit environmental conservation by stimulating new values, or else create resentment and generate further environmental aggression. By linking EE and ethnoecology, participative management can be conceived of as a genuine possibility, as opposed to current treatment of local people, especially in situations in which their mode of survival is threatened, as mere information receivers.

Respect for these communities and those of other bio-regions depends on more broadly conceived biodiversity values, which recognize and respect these cultures' connection to nature itself (Sato et al., 2002). Santos et al. (2000), in criticizing the limitations of EE projects based only on the natural contents of the Conservation Units, suggested a model based on local realities and the interaction of human beings and nature. Such a model would consider the whole spectrum of the environmental system: the intermingling of physical and biological elements, as well as structural and functional components, including related social and economic dimensions.

The importance of ethnoecologically-focused research rests on the desirability of the principle of co-management, which is in the hands of both the government and the population affected. This not only demonstrates respect for knowledge acquired outside the realm of academe or technical-administrative structures, but above all, honors a people's right to political respect, to participate in solving their own problems, and in the way "to [make] use of themselves" (Roué, 1997, apud Sato et al., 2002).

\section{FINAL CONSIDERATIONS}

The designation of the Environmental Protection Area (EPA) of Guaraqueçaba as important remains of the Atlantic Rainforest, and the manner in which it was created two decades ago, has been causing serious social problems until today. The greatest reason for this is the failure to inform the local population about the importance of legally conserving this area by making of it a conservation unit designed to insure biodiversity. Creating the Superagui National Park and the local conservation unit, far from being an idea of the residents, happened basically as a response to pressure exerted by environmental organizations and state agencies concerned with preserving threatened ecosystems. However, it is a presently recognized fact that diversity conservation strategies designed for regional ecosystems cannot be dissociated from the forms of human populational organization in these areas (Sato \& Passos, 2002). The current destructuralization of economic, social, and cultural processes, which increasingly affects communities composed of subsistence fishermen, represents a real threat to the continuation of a unique 
lifestyle, along with the local cultural and natural patrimony. This lifestyle, typical of social groups profounded linked to the natural world, has been disrupted by a complex group of exogenous elements (SPVS, 1995) mainly including the conservation units created, as well as fishing restrictions, urban expansion, real estate speculation, and tourism development. The results have been not only economic, but also the undermining of previous community socio-cultural points of view, which has gradually affected local social organization.

Those changes are obvious when examining the fishing community's relationships with the terrestrial environment, which is naturally less disciplined and complex as those characterizing continental agricultural communities. For the reasons already enumerated, the island inhabitants' access to the forest and its natural resources are yet more limited and incursions therein are ever rarer due to fear of encountering law enforcers. Therefore, the fishermen's daily life is restricted to sea and village, with knowledge of local fauna and flora gradually being lost. At the same time, environmental discourse, while ever more frequently heard, is not yet understood and, even when it is, at least in part rejected.

At the same time, what is left of the accumulated knowledge with respect to the terrestrial environment, e.g., the natural cycles of island animal life, the occurrence and abundance of animal species, as well as their uses and the values they represent, can yet be when added to the results of studies such as this, becoming be useful instruments in expanding the focus of conservation unit planning and management. Environmental education may, in this way, reflect a politically serious dialogue, aiming not at instructing passive students, but at creating partnerships, in the service of biological as well as cultural survival and to arrive at viable alternatives of sustainable development.

The EE principles are fully compatible with the premises of ethnoecology studies, since both are involved with conserving cultural and biological diversity through the understanding of, respect for, and propagation of accumulated community knowledge and traditional practices. Without social justice, $\mathrm{EE}$ or public management programs and strategies designed to bring about sustainable development are doomed to failure. By including and respecting locally accumulated knowledge regarding the functioning of environmental systems, the chances of all participants emerging as winners are significantly improved (Nordi et al., 2001).

\section{REFERENCES}

ADAMS, C., 2000, Caiçara na Mata Atlântica: pesquisa científica versus planejamento e gestão ambiental. Ed. Annablume/ Fapesp, São Paulo, 337p.

BEGOSSI, A., 2000, Resilience and neo-traditional populations: the caiçaras (Atlantic Forest) and caboclos (Amazon, Brazil). In: K. Berkes \& C. Folke (eds.), Linking social and ecological systems. Cambridge University Press, Uk.

BOGDAN, R. C. \& BIKIEN, S. K., 1994, Investigação qualitativa em educação. Porto Editora, Porto.

CHIZZOTTI, A., 1995, Pesquisa em ciências humanas e sociais. Cortez, São Paulo.

DA SILVA, V. C. F., 2000, Pesca e uso comunitário do espaço costeiro na ilha do Cardoso, litoral sul de São Paulo, Brasil. In: A. C. Diegues \& V. M. Viana (orgs.), Comunidades tradicionais e manejo dos recursos naturais da Mata Atlântica. USP-Nupaub/ESALQ-Lastrop, São Paulo, 273p.

DIEGUES, A., 1994, O mito moderno da natureza intocada. USP/Nupaub, São Paulo, 163p.

DIEGUES, A. \& NOGARA, P. J. N., 1994, O nosso lugar virou parque: estudo sócio-ambiental do Saco do Mamanguá, Paraty, Rio de Janeiro. USP/Nupaub, São Paulo, 187p.

DIEGUES, A. \& ARRUDA, R. S. V., 2001, Saberes tradicionais e biodiversidade no Brasil. Ministério do Meio Ambiente, Brasília, USP, São Paulo, 176p. (Biodiversidade, 4).

GEERTZ, C., 1973, The interpretation of cultures. Scientific Books, New York.

GIL, A. C., 1999, Métodos e técnicas de pesquisa social. Atlas, São Paulo.

HANBURY-TENISON, R., 1991, Povos tribais. pp. 137-141. In: J. Porrit (ed.), Salve a Terra. Círculo do Livro, São Paulo.

INSTITUTO PARANAENSE DE DESENVOLVIMENTO ECONÔMICO E SOCIAL (IPARDES), 1997, Zoneamento ecológico-econômico da APA de Guaraqueçaba. IPARDES, Curitiba, vol. 2, Versão preliminar, 212p.

MALDONADO, W., 1997, Comunidades caiçaras e o Parque Estadual de Ilhabela. pp. 123-136. In: A. C. Diegues (org.), Ilhas e sociedades insulares. USP/Nupaub, São Paulo.

MARQUES, J. G. W., 1995, Pescando pescadores: etnoecologia abrangente no baixo São Francisco alagoano. USP/Nupaub, São Paulo.

MUSSOLINI, G., 1980, Ensaios de antropologia indígena e caiçara. Ed. Paz e Terra, Rio de Janeiro, 288p.

MYERS, N., MITTERMEIER, R. A., MITTERMEIER, C. G., DA FONSECA, C. A. \& KENT, J., 2000, Biodiversity hotspots for conservation priorities. Nature, 403: 853-858.

NATIONAL ACADEMY OF SCIENCE (NAS), 1992, Conserving biodiversity - a research agenda for development agencies. National Academy Press, Washington, D.C., 125p. 
NORDI, N., THÉ, A. P. G., MOURÃO, J. S., MADI, E. F., CAVALLINI, M. \& MONTENEGRO, S. C. S., 2001, Etnoecologia, educação ambiental e desenvolvimento sustentável. pp. 133-144. In: J. E. SANTOS \& M. SATO (orgs.), A contribuição da educação ambiental à esperança de Pandora. RiMa, São Carlos.

POSEY, D. A., 1987, Etnobiologia: teoria e prática. pp. 15-25. In: D. Ribeiro (ed.), Suma etnológica brasileira. vol. 1. Vozes/ Finep, Petrópolis.

SANTOS, J. E., SATO, M., SALATIEL, J. S. \& MAROTI, P. S., 2000, Environmental education praxis toward a natural conservation area. Rev. Bras. Biol, 60(3): 361-372.

SATO, M. \& PASSOS, L., 2002, Biorregionalismo - identidade histórica e caminhos para a cidadania,. pp. 221-252. In: L. F. Loureiro, P. Layargues \& R. S. Castro (orgs.), Educação ambiental: repensando o espaço da cidadania. Cortez, São Paulo.

SATO, M., TAMAIO, I. \& MEDEIROS, H., 2002, Reflexos das cores amazônicas no mosaico da educação ambiental. WWFBrasil, Brasília.

SOCIEDADE DE PESQUISA EM VIDA SELVAGEM E EDUCAÇÃO AMBIENTAL (SPVS), 1995, Relatório de pesquisa do projeto co-gestão de manejo ambiental $e$ desenvolvimento comunitário na APA de Guaraqueçaba: comunidades pesqueiras da APA de Guaraqueçaba: uma caracterização sociocultural. IBAMA, Curitiba, 57p.

SOCIEDADE DE PESQUISA EM VIDA SELVAGEM E EDUCAÇÃO AMBIENTAL (SPVS), 1998, Projeto de educação ambiental para a conservação do papagaio-da-cararoxa (Amazona brasiliensis), Guaraqueçaba, PR. SPVS, Curitiba.
SOCIEDADE DE PESQUISA EM VIDA SELVAGEM E EDUCAÇÃO AMBIENTAL (SPVS), 1999, Subprojeto gerenciamento de área especial para a região de Guaraqueçaba, Paraná. SPVS/MMA/MCT-CNPq, Curitiba. Relatório de execução técnica.

UNIÃO INTERNACIONAL PARA A CONSERVAÇÃO DA NATUREZA (UICN), 1984, Estratégia mundial para a conservação: a conservação dos recursos vivos para um desenvolvimento sustentado. CESP, São Paulo.

THE WORLD CONSERVATION UNION (UICN), UNITED NATIONS ENVIRONMENT PROGRAM - PNUMA, WORLD WILDLIFE FUNDATION (WWF), 1991, Cuidando do planeta Terra: uma estratégia para o futuro da vida. UICNPNUMAWWF, São Paulo, 246p.

VIANNA, L. P., 1996, Considerações críticas sobre a construção da idéia de população tradicional no contexto das unidades de conservação. Dissertação de Mestrado em Antropologia, Faculdade de Filosofia, Letras e Ciências Humanas, Universidade de São Paulo, São Paulo.

VIVEKANANDA, G., 2001, Parque Nacional do Superagui: a presença humana e os objetivos de conservação. Dissertação de Mestrado em Conservação da Natureza, Universidade Federal do Paraná, Curitiba, 128p.

WORLD RESOURCES INSTITUTE (WRI), 1992, World resources 1992/93. Oxford University Press, Oxford. 